\author{
Adam RADKOWSKI ${ }^{1 *}$, Iwona RADKOWSKA ${ }^{2}$, Tadeusz LEMEK ${ }^{3}$ \\ and Tomasz JAKUBOWSKI ${ }^{4}$
}

\title{
EFFECT OF ZINC AMMONIUM ACETATE ON CHARACTERISTICS OF TIMOTHY CANOPY AND SEED YIELD
}

\author{
WPEYW OCTANU AMONU CYNKU \\ NA WŁAŚCIWOŚCI TYMOTKI ŁĄKOWEJ I PLON NASION
}

\begin{abstract}
The purpose of the experiment was to assess the effect of application of zinc ammonium acetate (ZAA) on yielding, morphological features and on selected vegetation indices of timothy cv. 'Owacja' cultivated for seeds. Zinc ammonium acetate that has a biostimulatory effect was used foliar in the carried out experiment. The experiment was conducted in the years 2015-2017 at the experimental station in Prusy near Krakow, a part of the Experimental Station of the Institute of Crop Production of the University of Agriculture in Krakow. The field experiment was set up in a randomized block design, in four replications, and the area of experimental plots was $10 \mathrm{~m}^{2}$. Degraded Chernozem formed from loess (classified to the first class quality soil) was present on the experimental area. The experiment consisted in applying ZAA as spray at three doses: $0.214,0.267$ and $0.400 \mathrm{~kg}\left(\mathrm{ZnNH}_{4}\left(\mathrm{CH}_{3} \mathrm{CO}_{2}\right)_{3}\right) / \mathrm{ha}$. Based on the obtained preliminary results, it was found that application of foliar activator in a higher dose $(0.400 \mathrm{~kg} / \mathrm{ha})$ caused a significant $(p \leq 0.05)$ increase in seed yield, 1000 -seed weight and in germination capacity in relation to the control. Improvement in morphological properties was also observed. Leaf greenness index (SPAD) was also determined. Its highest value was found in plants from the treatment where the highest dose of the zinc ammonium acetate was applied. Seeds obtained from plants treated with ZAA were riper (ripeness was measured with 1000-seed weight) and had higher germination capacity in relation to control treatments.
\end{abstract}

Keywords: seed plantation, growth promoter, zinc ammonium acetate, 1000-seed weight, SPAD - leaf greenness index, timothy

\footnotetext{
${ }^{1}$ Department of Agroecology and Crop Production, University of Agriculture in Kraków, al. A. Mickiewicza 21, 31-120 Kraków, Poland

${ }^{2}$ Department of Cattle Breeding, National Research Institute of Animal Production, ul. Krakowska 1, 32-083 Balice, Poland

${ }^{3}$ Department of Biopolymer Chemistry, Institute of Chemistry, University of Agriculture in Kraków, ul. Balicka 122, 30-149 Kraków, Poland

${ }^{4}$ Department of Machinery, Ergonomics and Production Processes, University of Agriculture in Krakow, ul. Balicka 116 b, 30-149 Kraków, Poland

*Corresponding author: adam.radkowski@urk.edu.pl
} 


\section{Introduction}

In modern plant cultivation, apart from basic mineral fertilization, various products called plant growth regulators or biostimulants are more and more often used [1-3]. Biostimulants stimulate development of whole plants or specific organs, accelerate life processes and enhance plant resistance to stress factors like high temperature, low humidity, and salt [4]. The application of certain active substances allows obtaining the highest possible yield efficiency and quality, particularly under environmental conditions unfavorable for plant growth and development [5-7]. Timothy (Phleum pratense L.) belongs to species commonly cultivated in cold and humid regions of the world. However, shallow root system and low tolerance to drought resulting from it are a considerable limitation to its cultivation. By using certain substances, the so-called auxin cofactors, one can stimulate the root system growth, this way also influencing the plant growth. Auxin cofactors include certain microelements, for instance zinc. This element has a number of biochemical functions in plants. Among others, it improves nitrogen metabolism in plants, has a beneficial effect on nitrogen transformations, which results in higher plant growth. Zinc also has numerous enzymatic functions, takes part in photosynthesis and in transcription, controls reaction in the cytoplasm, and also plays structural roles (being an integral part of cell membranes) [8, 9]. Zinc in $\mathrm{ZnNH}_{4}\left(\mathrm{CH}_{3} \mathrm{CO}_{2}\right)_{3}$ (zinc ammonium acetate ZAA) by forming a complex with an organic acid is readily available for plants and is quickly absorbed. The application of zinc in such form has a positive effect on the capacity for nutrient uptake and accumulation, a positive effect on the dynamic development of root mass, better initial development of plants and higher tolerance to the stress associated with low temperature and water deficiency. When applied at early developmental stages, it stimulates the production of auxins by plants, which influences intensification of cell divisions and the longitudinal growth of the root system. In aquatic environment, zinc ammonium acetate undergoes dissociation according to the equation:

$$
\mathrm{ZnNH}_{4}\left(\mathrm{CH}_{3} \mathrm{CO}_{2}\right)_{3} \rightleftarrows 3 \mathrm{CH}_{3} \mathrm{COO}^{-}+\mathrm{NH}_{4}^{+}+\mathrm{Zn}^{2+}
$$

and releases acetate, ammonium and zinc ions, all of which then undergo hydrolytic equilibrium reactions described below. The position of these equilibria depends on the environment $\mathrm{pH}$ value. $\mathrm{pH}$ of the soil is also important factor influencing the bioavailibity of zinc if applied to the soil [10].

$$
\begin{gathered}
\mathrm{CH}_{3} \mathrm{COO}^{-}+\mathrm{H}_{2} \mathrm{O} \rightleftarrows \mathrm{CH}_{3} \mathrm{COH}+\mathrm{OH}^{-} \\
\mathrm{Zn}^{2+}+4 \mathrm{H}_{2} \mathrm{O} \rightleftarrows \mathrm{Zn}(\mathrm{OH})_{2}+2 \mathrm{H}_{3} \mathrm{O}^{+} \\
\mathrm{NH}_{4}^{+}+\mathrm{H}_{2} \mathrm{O} \rightleftarrows \mathrm{NH}_{3}+\mathrm{H}_{3} \mathrm{O}^{+}
\end{gathered}
$$

Therefore, the purpose of the research was to determine the effect of foliar application of zinc ammonium acetate on yielding, morphological features and on selected vegetation indices of timothy cv. 'Owacja' cultivated for seeds.

\section{Materials and methods}

The research was carried out in the years 2015-2017 at the experimental station in Prusy near Krakow, a part of the Experimental Station of the Institute of Crop Production of the University of Agriculture in Krakow. Chemical properties of the soil were as follows: $\mathrm{pH}_{\mathrm{KCl}}-6.9$, and available elements in the following amounts: $\mathrm{P}$ - 46.0; $\mathrm{K}$ - 126.3, $\mathrm{Mg}-42.4 \mathrm{mg} / \mathrm{kg}$ and $\mathrm{Zn} 12.7 \mathrm{mg} / \mathrm{kg}$. Total annual precipitation in the research period 
(years 2015-2017) ranged from 529.8 to $810.4 \mathrm{~mm}$ (Fig. 1). Mean total precipitation in the growing season (April-September) was within the limits from 338.6 to $573.0 \mathrm{~mm}$.

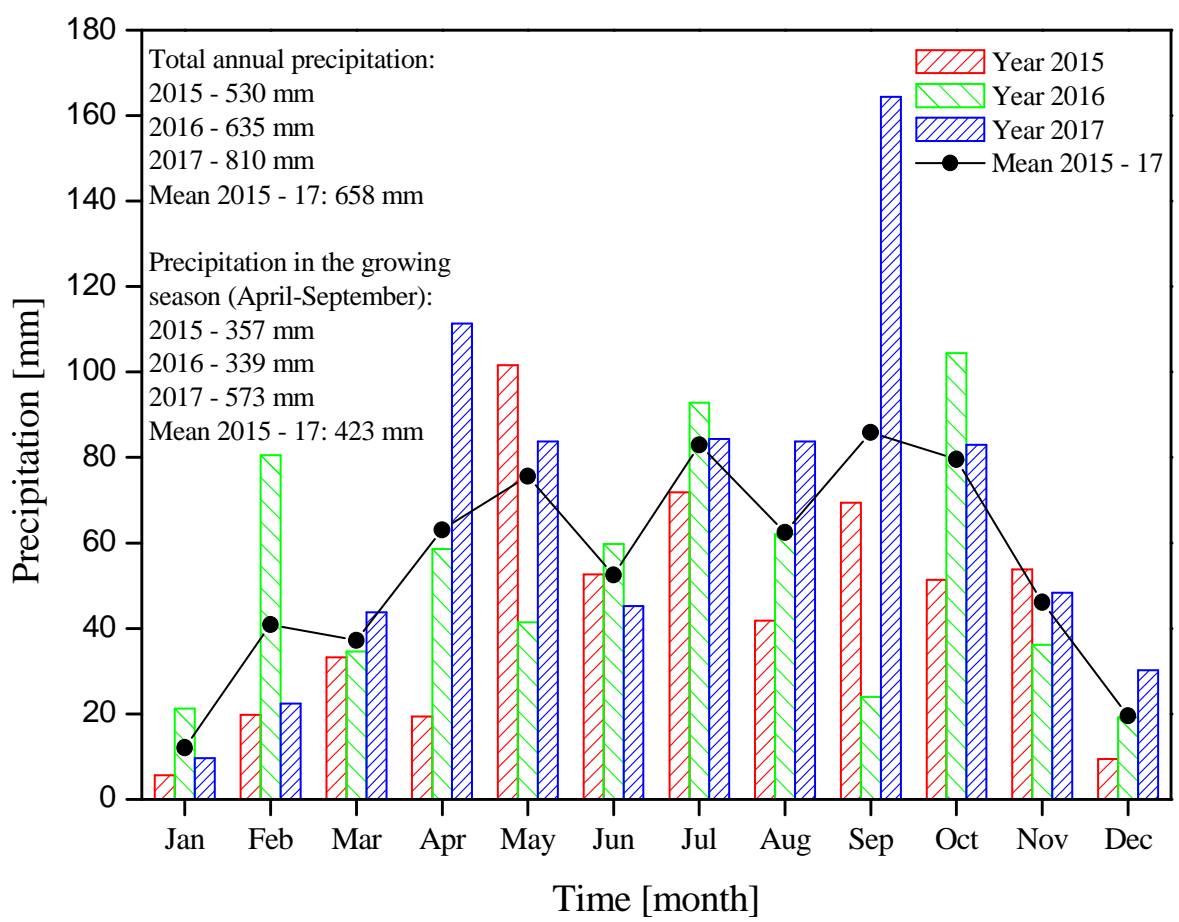

Fig. 1. Monthly and mean annual precipitation between 2015 and 2017 (Prusy Experimental Station of the University of Agriculture in Krakow)

Mean annual temperature in the research years varied from 9.3 to $10.2{ }^{\circ} \mathrm{C}$, and from 15.6 to $16.3{ }^{\circ} \mathrm{C}$ between April and September (Fig. 2).

The experiment that was set up in a randomized block design in four replications (plots: $1 \times 10.0 \mathrm{~m}^{2}$ ) took into account four treatments: control (without using the product) and experimental - sprayed with zinc ammonium acetate (ZAA) at three doses: 0.214, 0.267 and $0.400 \mathrm{~kg} / \mathrm{ha}$. ZAA doses in this preliminary investigations have been chosen arbitrary without former optimization of the ZAA amount. The first dose was applied after plant emergence, and successive doses were applied after the beginning of spring vegetation. The solutions for spraying were prepared by dissolving appropriate quantities of zinc ammonium acetate in demineralized water with rest conductivity $\sigma=0.29 \mu \mathrm{S}$ and $\mathrm{pH}=5.7$ to form a $1 \%$ stock solution of ZAA and then its dilution in such water volume so as to obtain the working liquid volume corresponding to $300 \mathrm{dm}^{3} /$ ha [11]. The zinc ammonium acetate used in the experiment was supplied by Intermag Ltd. in Olkusz. The research was conducted on timothy (Phleum pratense L.) cv. 'Owacja'. This cultivar has been registered in the National Register since 28 Feb 2014, and is bred by Malopolska Plant Breeding Company - HBP Limited Partnership in Krakow. The rate of seeding for timothy was $4 \mathrm{~kg} \cdot \mathrm{ha}^{-1}$. The cultivar used in the research was sown without a nurse-crop. 


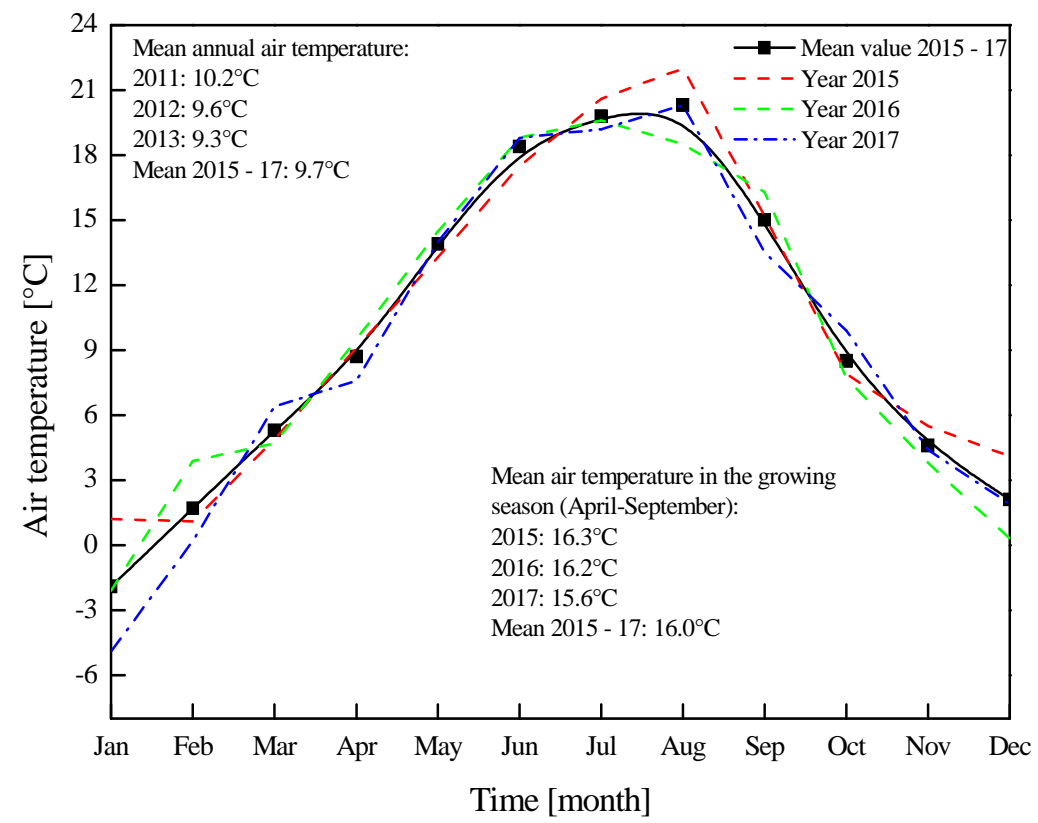

Fig. 2. Monthly and mean annual temperature between 2015 and 2017 (Prusy Experimental Station of the University of Agriculture in Krakow)

Mineral soil fertilization was applied at the following doses: $50 \mathrm{~kg} \mathrm{~N} / \mathrm{ha}$ before sowing in the form of ammonium nitrate, $26.2 \mathrm{~kg} \mathrm{P} / \mathrm{ha}$ in the form of enriched superphosphate and $66.4 \mathrm{~kg} \mathrm{~K} / \mathrm{ha}$ in the form of $57 \%$ potassium salt. Moreover, in autumn, phosphorus and potassium were applied for top dressing in the same quantities and forms as before sowing. Similarly in the years of full use, the same doses of phosphorus and potassium (in the same form) were used in autumn. Nitrogen fertilization of timothy was divided into three parts. The first part of nitrogen was applied after collecting timothy seeds at a dose of $40 \mathrm{~kg} \mathrm{~N} / \mathrm{ha}$, the second part was applied in spring (at the beginning of vegetation) in the amount of $20 \mathrm{~kg} \mathrm{~N} / \mathrm{ha}$ and at the turn of April and May (40 kg N/ha).

In individual years of the experiment, the effect of foliar fertilization on chlorophyll content was investigated. Leaf greenness index (SPAD) was measured on the upper leaves using a Minolta SPAD 502 DL chlorophyll meter. The measurements were taken on thirty fully developed leaves in each plot. Morphological measurements were conducted on generative tillers in the flowering stage (June). The height of plants, inflorescence length and width as well as flag leaf blade length and width were measured. Timothy seeds were harvested at the turn of the third decade of July and first days of August using a plot combine (Wintersteiger, Model NM-Elite). After seed harvest, straw and crop residue were removed from the plots. After threshing, the seeds were cleaned and dried up to $14 \%$ moisture content. The 1000-seed weight and the germination capacity were determined separately for each plot in the samples collected after threshing, drying up and cleaning. Germination capacity was calculated after 10 days using Jacobsen germination apparatus according to PN-79/R-65950 standard [12]. Results were subjected to analysis of variance, 
and the significance of differences was assessed by Duncan test $(\alpha=0.05)$ using Statistica 10 PL software.

\section{Results and discussion}

Zinc is an indispensable element for the development of higher plants and is classified as a soil microelement [13]. At the same time, it is toxic to plants when present in high concentration [14]. Also significant is the form of zinc occurring in soil as it decides on its assimilability by plants. This form can be determined using adequate analytical methods e.g. direct extraction of $\mathrm{Zn}$ with diethylenetriamine pentaacetic acid (DTPA) or stepwise determination with $\mathrm{CaCl}_{2}$ extraction [15]. In our experiment $\mathrm{Zn}$ concentration in applied soil was $12.7 \mathrm{mg} / \mathrm{kg}$, this is about the lower limit of $\mathrm{Zn}$ concentration, below which critical shortage is observed [16]. If zinc concentration in soil is too low or in the case of poor zinc availability, it can be delivered to plants through foliar application using products that contain zinc in a form readily assimilable by plants. Based on the conducted analyses and measurements, we found that foliar application of diluted water solution of zinc ammonium acetate at different doses $(0.214,0.267$ and $0.400 \mathrm{~kg} / \mathrm{ha})$ had a significant effect on the investigated parameters, such as tiller height, flag leaf length and width, inflorescence length and width, and chlorophyll concentration. Results of the morphological properties of timothy plants are presented in Table 1. Data of three-year research show a significant, beneficial effect of applying zinc ammonium acetate on morphological properties of plants. Plants from the treatment where fertilization was applied at a dose of $0.400 \mathrm{~kg} / \mathrm{ha}$ were much higher and developed longer inflorescences and leaf blades compared to the other treatments. In the case of those without foliar application, plants had distinctly shorter tillers.

Table 1

\section{Comparison of morphological properties of timothy plants depending on dose of ZAA} (means from three years of research)

\begin{tabular}{|c|c|c|c|c|c|}
\hline $\begin{array}{c}\text { Dose of ZAA } \\
{[\mathbf{k g} / \mathbf{h a}]}\end{array}$ & $\begin{array}{c}\text { Tiller length } \\
{[\mathbf{c m}]}\end{array}$ & $\begin{array}{c}\text { Flag leaf length } \\
{[\mathbf{c m}]}\end{array}$ & $\begin{array}{c}\text { Flag leaf width } \\
{[\mathbf{c m}]}\end{array}$ & $\begin{array}{c}\text { Inflorescence } \\
\text { length } \\
{[\mathbf{c m}]}\end{array}$ & $\begin{array}{c}\text { Inflorescence } \\
\text { width } \\
{[\mathbf{c m}]}\end{array}$ \\
\hline Control & $111.0( \pm 3.4)^{\mathrm{b}}$ & $5.5( \pm 1.1)^{\mathrm{b}}$ & $0.37( \pm 0.05)^{\mathrm{b}}$ & $3.72( \pm 0.74)^{\mathrm{b}}$ & $0.51( \pm 0.05)^{\mathrm{b}}$ \\
\hline 0.214 & $114.8( \pm 3.3)^{\mathrm{b}}$ & $5.6( \pm 1.3)^{\mathrm{b}}$ & $0.39( \pm 0.04)^{\mathrm{ab}}$ & $3.87( \pm 0.61)^{\mathrm{ab}}$ & $0.53( \pm 0.06)^{\mathrm{ab}}$ \\
\hline 0.267 & $116.5( \pm 3.2)^{\mathrm{ab}}$ & $5.77( \pm 0.95)^{\mathrm{ab}}$ & $0.39( \pm 0.02)^{\mathrm{ab}}$ & $3.88( \pm 0.45)^{\mathrm{ab}}$ & $0.54( \pm 0.05)^{\mathrm{ab}}$ \\
\hline 0.400 & $117.3( \pm 2.1)^{\mathrm{a}}$ & $5.88( \pm 0.84)^{\mathrm{a}}$ & $0.40( \pm 0.02)^{\mathrm{a}}$ & $3.94( \pm 0.32)^{\mathrm{a}}$ & $0.55( \pm 0.03)^{\mathrm{a}}$ \\
\hline
\end{tabular}

$\mathrm{a}, \mathrm{b}, \mathrm{c}$ - values in columns marked with different letters differ significantly $(p \leq 0.05)$

Chlorophyll index SPAD in timothy cv. 'Owacja' at different developmental stages depending on the dose of ZAA (mean values from three years of the research)

\begin{tabular}{|c|c|c|c|c|}
\hline \multirow{2}{*}{ Dose of ZAA [kg/ha] } & \multicolumn{4}{|c|}{ Developmental stage } \\
\cline { 2 - 5 } & Stem elongation & Head emergence & Anthesis & Milky ripeness \\
\hline Control & $34.7( \pm 1.3)^{\mathrm{b}}$ & $37.5( \pm 1.2)^{\mathrm{b}}$ & $39.8( \pm 1.1)^{\mathrm{b}}$ & $33.6( \pm 1.4)^{\mathrm{b}}$ \\
\hline 0.214 & $35.3( \pm 1.0)^{\mathrm{b}}$ & $39.1( \pm 0.8)^{\mathrm{ab}}$ & $41.1( \pm 0.9)^{\mathrm{ab}}$ & $34.3( \pm 1.2)^{\mathrm{ab}}$ \\
\hline 0.267 & $36.2( \pm 0.6)^{\mathrm{ab}}$ & $39.4( \pm 2.2)^{\mathrm{ab}}$ & $41.5( \pm 0.7)^{\mathrm{ab}}$ & $34.6( \pm 0.8)^{\mathrm{ab}}$ \\
\hline 0.400 & $36.8( \pm 0.7)^{\mathrm{a}}$ & $39.9( \pm 2.4)^{\mathrm{a}}$ & $42.0( \pm 2.0)^{\mathrm{a}}$ & $35.4( \pm 2.2)^{\mathrm{a}}$ \\
\hline
\end{tabular}

$\mathrm{a}, \mathrm{b}, \mathrm{c}$ - values in columns marked with different letters differ significantly $(p \leq 0.05)$ 
Measurements of chlorophyll content in leaves showed significant diversity in terms of the used foliar fertilization (Table 2). Mean SPAD readings in the research years were higher $(p \leq 0.05)$ in treatments were higher doses of the product $(0.400 \mathrm{~kg} / \mathrm{ha})$ compared to the control were applied. An increase in SPAD readings depending on date of measurement was also observed. These values continued to increase up to the flowering stage. The value of leaf greenness index (SPAD) of the plants varied depending on the date of measurement from 33.62 to 41.98 .

Timothy seed yield ranged from 798 (2017) to $1054 \mathrm{~kg} / \mathrm{ha}$ (2015) (Fig. 3). When increasing the dose of the product, the seed yield also increased. The highest yield $(p \leq 0.05)$ was observed at application of $0.400 \mathrm{~kg} / \mathrm{ha}$. The increase in yield resulted mainly from the increase in weight of grains, that from their ripeness.

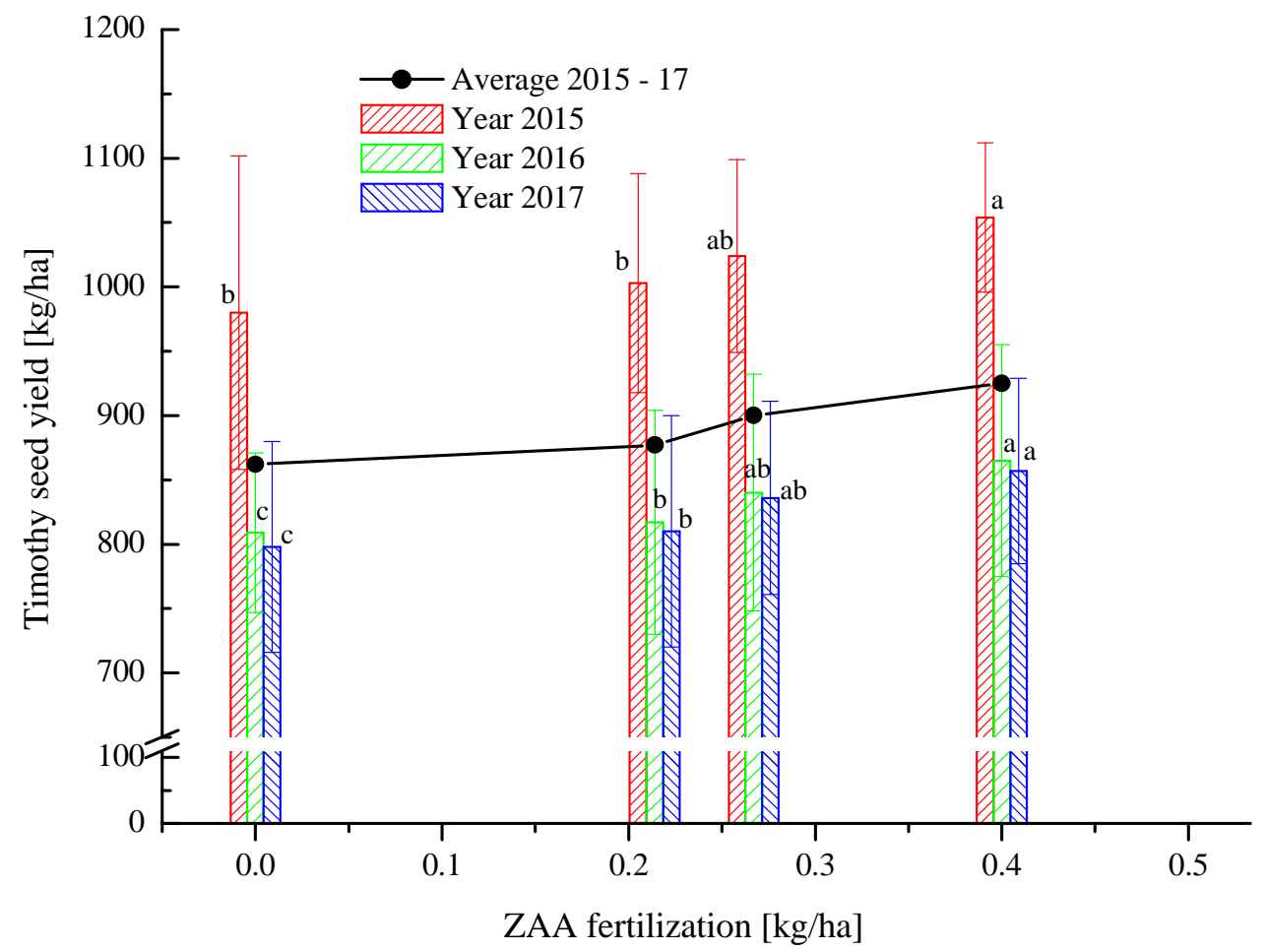

Fig. 3. Timothy seed yield [kg/ha] depending on dose of zinc ammonium acetate, a, b, c - values marked with different letters differ significantly $(p \leq 0.05)$

Literature review indicates that, the use of zinc ammonium acetate, either ammonium acetate or acetate alone [17] or zinc $(\mathrm{Zn})[18,19]$ has an effect on yielding. In his field experiment with corn and soybean, Thasanasongchan [17] examined six chemicals containing acetate ion (including zinc ammonium acetate) and established, that responses to yielding were caused by acetate alone, since it was a component of each of the tested compound. After applying zinc ammonium acetate, he determined that zinc could have had a greater effect than ammonium acetate alone. In addition, some proofs suggest 
a synergistic effect of $\mathrm{Zn}$ and the acetate component [17]. By contrast, Khosravi [19] suggested that acetate ions can act as a complexing ligand to increase $\mathrm{Zn}$ availability with simultaneous preservation of acetate metabolism by soil microflora. The applied fertilization had a significant effect also on the 1000-seed weight. The best results were obtained in the treatment, where the highest dose of the zinc ammonium acetate $(0.400 \mathrm{~kg} / \mathrm{ha})$ was applied (Fig. 4).

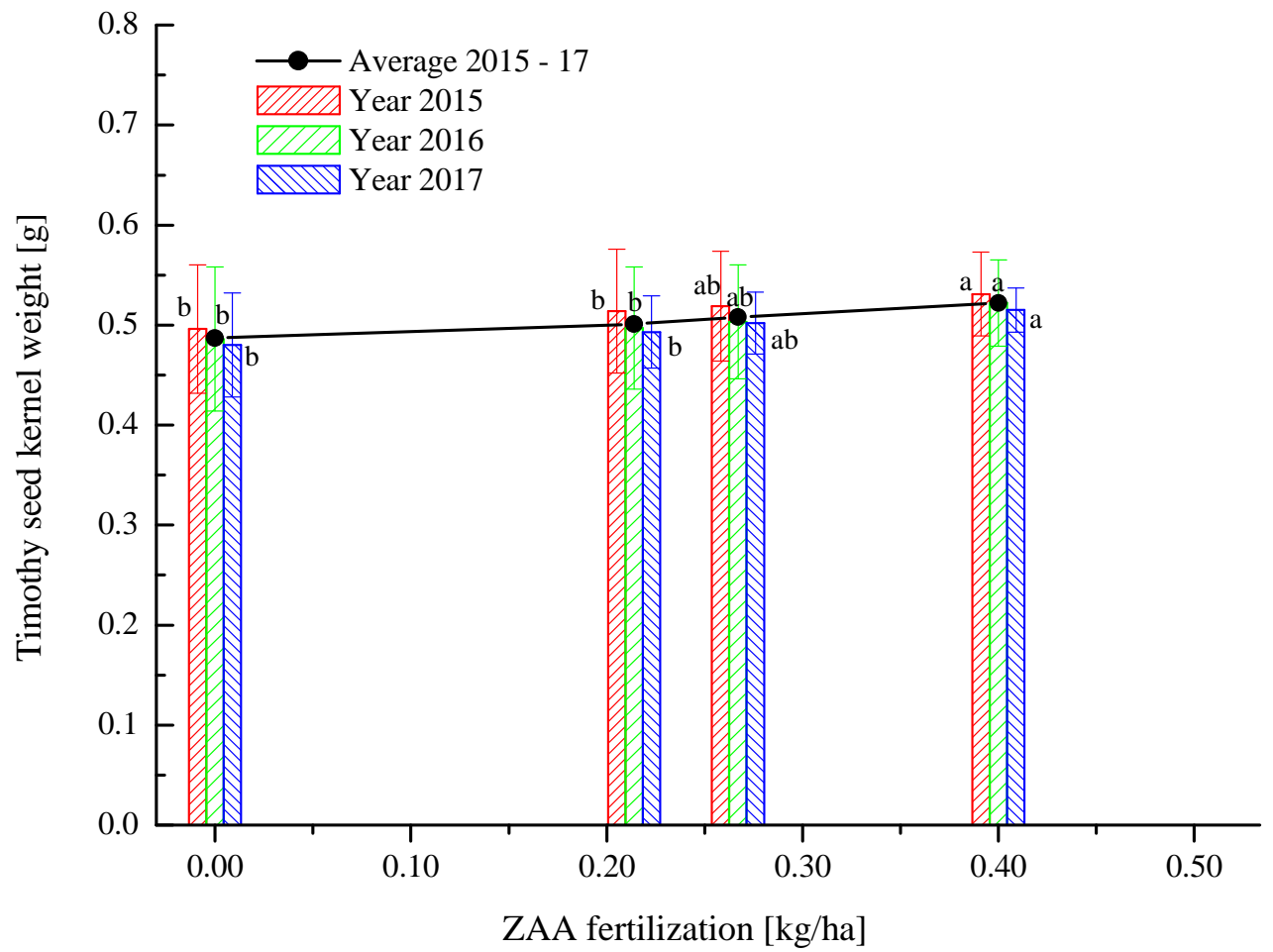

Fig. 4. 1000-seed (timothy) weight depending on dose of zinc ammonium acetate, a, b - values marked with different letters differ significantly $(p \leq 0.05)$

Values from this treatment greatly exceeded the 1000-seed weight obtained in the control treatments. Thasanasongchan, Khosravi, and Liu et al. [17, 19, 20] showed that application of ZAA increases the grain yield of field corn as a result of increased weight per kernel. Table 3 shows the germination capacity of timothy seeds. The value of this parameter depended significantly on the applied dose of ZAA. The highest values $(p \leq 0.05)$ were recorded in treatments where the $0.400 \mathrm{~kg} / \mathrm{ha}$ dose was applied. Germination capacity was highest in the first year of using the seed plantation, and decreased in subsequent years of utilization. In their isotopes studies, Liu et al. [20] showed that zinc ammonium acetate enhanced cytokinin levels in root and shoot tissues of corn seedlings, which pointed to a secondary regulatory effect of ZAA in improving corn productivity. Liu et al. [21] evaluated the effect of four concentrations $(0,0.85,8.5$ and $85 \mathrm{ppm}$ ) of ZAA on laboratory germination and early growth of three genotypes of corn. 
In their greenhouse test, leaf area, plant height and dry weight of shoots of 3-week-old seedlings of all genotypes were increased by ZAA at 0.85 and $8.5 \mathrm{ppm}$. Research conducted by Pacholczak and Szydło [22] showed a positive effect of ammonium zinc acetate on the rooting of stem cuttings of ninebark (Physocarpus opulifolius). All treatments considerably improved rooting compared to untreated controls. Spraying the cuttings with the product containing zinc was as effective as the two rooting: the average shoot length in sprayed the cuttings was several times longer than that of the control [23]. Ammonium zinc acetate has been recently used to stimulate root growth of numerous agricultural crops (e.g. corn or rape). Crops with enhanced root growth are less prone to drought, and so they yield better. Ammonium zinc acetate applied at very low concentration as in described experiment can be usually combined with other fertilize, a practice that reduced the number of treatments. We assume, that with treatment of timothy by ammonium zinc acetate $0.400 \mathrm{~kg} / \mathrm{ha}$ in our case of soil (contained $12.7 \mathrm{mg} / \mathrm{kg} \mathrm{Zn}$ ) we reach the optimal dose of ammonium zinc acetate because the seed yield as well seed weight seems to reach a plateau on Figures 3 and 4 .

Table 3

Germination capacity [\%] of timothy seeds depending on dose of ZAA

\begin{tabular}{|c|c|c|c|c|}
\hline \multirow{2}{*}{ Dose of ZAA [kg/ha] } & \multicolumn{3}{|c|}{ Years } & \multirow{2}{*}{ Mean } \\
\cline { 2 - 4 } & $\mathbf{2 0 1 5}$ & $\mathbf{2 0 1 6}$ & $\mathbf{2 0 1 7}$ & \\
\hline Control & $89.0( \pm 2.9)^{\mathrm{b}}$ & $88.5( \pm 2.6)^{\mathrm{b}}$ & $87.3( \pm 3.0)^{\mathrm{b}}$ & 88.3 \\
\hline 0.214 & $91.1( \pm 1.8)^{\mathrm{ab}}$ & $90.7( \pm 2.4)^{\mathrm{b}}$ & $90.2( \pm 1.6)^{\mathrm{ab}}$ & 90.7 \\
\hline 0.267 & $92.1( \pm 2.5)^{\mathrm{ab}}$ & $91.9( \pm 2.5)^{\mathrm{ab}}$ & $90.7( \pm 3.2)^{\mathrm{ab}}$ & 91.6 \\
\hline 0.400 & $94.7( \pm 3.1)^{\mathrm{a}}$ & $94.7( \pm 3.2)^{\mathrm{a}}$ & $93.3( \pm 3.2)^{\mathrm{a}}$ & 94.2 \\
\hline
\end{tabular}

$\mathrm{a}, \mathrm{b}$ - values in columns marked with different letters differ significantly $(p \leq 0.05)$

\section{Conclusions}

The preliminary results of a field experiment carried out on a seed plantation showed a positive effect of the use of zinc ammonium acetate (ZAA) on seed yield, morphological features and on selected vegetation indices of timothy cv. 'Owacja'.

Based on the obtained results, it was found that application of foliar ZAA in a higher dose $(0.400 \mathrm{~kg} / \mathrm{ha})$ caused a significant $(p \leq 0.05)$ increase in seed yield, 1000 -seed weight and in germination capacity in relation to the control. Improvement in morphological properties as well as leaf greenness index (SPAD) was also observed. Their highest value was found in plants from the treatment where the highest dose of ZAA was applied. Seeds obtained from plants treated with ZAA were riper (ripeness was measured with 1000 -seed weight) and had higher germination capacity in relation to control treatments. Implementation of the results presented in this work on farms needs further optimization of the ZAA doses depending on chemical properties of the available soils. However taking into account the necessity of a relatively small amounts of the ZAA and low risk of its overdosing one can predict the optimal dose of the ZAA in particular case on the base of our results presented here.

The observed improvement in some growth characteristics and yield on timothy seed plantations confirms the necessity of their use, indicating at the same time the need for further studies on the effect of ZAA on the development and seed yield of other fodder grasses. 


\section{Acknowledgements}

The research was financed by the Ministry of Science and Higher Education of the Republic of Poland.

\section{References}

[1] Calvo P, Nelson L, Kloepper JW. Agricultural uses of plant biostimulants. Plant Soil. 2014;383:3-41. DOI: 10.1007/s11104-014-2131-8.

[2] Radkowski A, Radkowska I. Effects of silicate fertilizer on seed yield in timothy-grass (Phleum pratense L.). Ecol Chem Eng S. 2018;25(1):169-80. DOI: 10.1515/eces-2018-0012.

[3] Radkowski A, Radkowska I. Influence of foliar fertilization with amino acid preparations on morphological traits and seed yield of timothy. Plant Soil Environ. 2018;64(5):209-13. DOI: 10.17221/112/2018-PSE.

[4] Vernieri P, Borghesi E, Ferrante A, Magnani G. Application of biostimulants in floating system for improving rocket quality. J Food Agric Environ. 2005;3(3-4):86-8. https://eurekamag.com/research/004/399/004399215.php.

[5] Przybysz A, Wrochna M, Słowiński A, Gawrońska H. Stimulatory effect of Asahi SL on selected plant species. Acta Sci Pol. Hortorum Cultus. 2010;9(2):53-64. http://www.acta.media.pl/pl/action/getfull.php?id=2321.

[6] Radkowski A, Radkowska I, Lemek T. Effects of foliar application of titanium on seed yield in timothy (Phleum pratense L.). Ecol Chem Eng S. 2015;22(4):691-701. DOI: 10.1515/eces-2015-0042.

[7] Radkowski A, Sosin-Bzducha E, Radkowska I. Effects of silicon foliar fertilization of meadow plants on the nutritional value of silage fed to dairy cows. J Elem. 2017;22(4):1311-22. DOI: 10.5601/jelem.2017.22.1.1331.

[8] Disante KB, Fuentes D, Cortina J. Response to drought of Zn-stressed Quercus suber L. seedlings. Env Exp Bot. 2010;70:96-103. DOI:10.1016/j.envexpbot.2010.08.008.

[9] Hafeez B, Khanif YM, Saleem M. Role of zinc in plant nutrition - A review. Am J Experimental Agricult. 2013;3(2):374-91. DOI: 10.9734/AJEA/2013/2746.

[10] Brennan RF, Bolland MDA. Zinc sulfate is more effective at producing wheat shoots than zinc oxide in an alkaline soil but both sources are equally effective in an acid soil. Australian J Experimental Agricult. 2006;46(12):1615-20. DOI: 10.1080/01904160801926228.

[11] $\mathrm{Wu} \mathrm{H}$, Rao ChV, Rambabu B. Electrochemical performance of $\mathrm{LiNi}_{0.5} \mathrm{Mn}_{1.5} \mathrm{O}_{4}$ prepared by improved solid statemethod as cathode in hybrid supercapacitor. Materials Chem Phys. 2009;116:532-5. DOI: 10.1016/j.matchemphys.2009.04.028.

[12] International Rules for Seed Testing. International Seed Testing Association, ISTA; 2020. Available from: https://www.seedtest.org/en/international-rules-for-seed-testing-_content---1--1083.html.

[13] Andresen E, Peiter E, Küpper H. Trace metal metabolism in plants. J Experim Botany. 2018;69(5):909-54. DOI: $10.1093 / \mathrm{jxb} / \mathrm{erx} 465$.

[14] Broadley M, Brown P, Cakmak I, Rengel Z, Zhao F. Function of nutrients: micronutrients. In: Marschner P, editor. Marschner's Mineral Nutrition of Higher Plants, 3rd ed. Academic Press; 2012; 191-248. DOI: 10.1016/B978-0-12-384905-2.00007-8.

[15] Duffner A, Hoffland E, Weng L, Sjoerd EATM van der Zee. Predicting zinc bioavailability to wheat improves by integrating $\mathrm{pH}$ dependent nonlinear root surface adsorption. Plant Soil. 2013;373:919-30. DOI: 10.1007/s11104-013-1845-3.

[16] Korzeniowska J, Stanislawska-Glubiak E, Kantek K, Lipinski W, Gaj R. Micronutrient status of winter wheat in Poland. J Central Europ Agricult. 2015;16(1):54-64. DOI: 10.5513/JCEA01/16.1.1540.

[17] Thasanasongchan A. The influence of acetates on growth and yield of corn (Zea mays L.) and soybean [Glycine max (L.) Merr.]. Ph.D. Dissertation. Ames, IA: Iowa State University; 1981. DOI: 10.31274/rtd-180813-5947.

[18] Ruffo M., Olson R., Daverede I. Maize yield response to zinc sources and effectiveness of diagnostic indicators. J. Comm. Soil Sci Plant Anal. 2016;47(2):137-41. DOI: 10.1080/00103624.2015.1108433.

[19] Khosravi G. The effect of hormones and chemical growth regulators on ear development and grain yield of nonprolific corn (Zea mays L.). Ph.D. Thesis. Ames, IA: Iowa State University; 1980. DOI: 10.31274/rtd-180813-11776.

[20] Liu A, Jones RJ, Malzer GL, Rehm GW. Fate of zinc ammonia acetate in soils and its uptake by corn. J Plant Nutrition. 2006;29(6):1003-19. DOI: 10.1080/01904160600686080. 
[21] Liu A, Jones RJ, Malzer GL, Rehm GM. Effect of zinc ammonia acetate on germination and early seedling growth of three maize genotypes. J Plant Nutrition. 2008;20(11):1551-66. DOI: 10.1080/01904169709365356.

[22] Pacholczak A, Szydło W. Effect of ammonium zinc acetate on rooting of stem cuttings in Physocarpus opulifolius. Ann Warsaw Univ Life Sci - SGGW, Horticult Landsc Architect. 2008;29:59-64. http://annals-wuls.sggw.pl/files/files/hla/hla2008no29art07.pdf.

[23] Bingham IJ, McCabe VB. Commercially available plant growth regulators and promoters modify bulk tissue abscisic acid concentrations in spring barley, but not root growth and yield response to drought. Annals Appl Biol. 2006;149:291-304. DOI: 10.1111/j.1744-7348.2006.00093.x. 